\title{
MINHA EXPERIÊNCIA COM UTI
}

\author{
Joel Martins *
}

\begin{abstract}
RESUMO - Após haver sido internado numa UTI, em São Paulo, o autor relata sua experiência com a própria doença, com os atendentes de enfermagem e critica severamente a indiferença e a postura desumana dos médicos, principalmente do diretor da UTI. Compara através de metáforas a UTI com o inferno de Dante. No seu discurso enfático, o autor pōe em evidência a aparente crença entre os profissionais da saúde de que um paciente é um Ser regressivo, e que precisa ser tratado com energia e sem qualquer demonstração de carinho e amizade. Mostra, então o autor, que aí está o grande engano, pois se houver regressão esta só pode ser compensada com atenção e carinho, pois não é possível que alguém deseje permanecer na UTI mais do que o mínimo imprescindivel para uma recuperação, posterior, no hospital.
\end{abstract}

ABSTRACT - After being admitted into an Intensive Care Unity, in São Paulo, the author reports his experiences with the illness itself, and with the nurses. Criticizes strongly their indifference and the inhuman behavior of the doctors, mainly the supervisor of the Unity. Through use of metaphors, he compares the Unity to Dante's description of Inferno. In his emphatic speech, the author puts|into evidence the apparent belief among the Health Professionals that a patient when admitted to a Hospital turns out to be regressive and needs to be taken care with objectivity without any attention or tenderness. This is a misconception, because it is impossible to admit that anyone would aim at staying at the Intensive Care Unity for more than the minimum necessary to recover from illness.

Sou Professor Universitário com uma experiência de alguns anos de vida e trabalho no campo do ensino e da pesquisa. Já ouvira falar em UTI no decorrer de minha vida acadêmica e social, mas nunca poderia pensar o que seria a experiência vivida na UTI.

$\mathrm{O}$ ano passado, após haver me resfriado, precisei fazer uma viagem, sem haver todavia logrado completo restabelecimento desse resfriado. Ao retornar, senti que minhas forças estavam se esvaindo e que eu sentia que ia morrer.

Ao chegar em minha casa, após algumas horas já inconsciente recebi auxílio de familiares que residem no mesmo conjunto.

Tem, então, início o primeiro drama na minha trajetória - o pronto-socorro. Ainda que eu possuísse um Plano Master de um conceituado sistema Nacional de Saúde de São Paulo, o atendimento em pronto-socorro é lento, precário, tumultuado pela afluência de pessoas. Finalmente, ainda inconsciente, fui levado para um Hospital quase nos arredores de São Paulo.
Ao chegar ali, fui posto num local que eu só vim saber qual era dois dias depois.

O que foi a UTI para mim. Ao despertar, gradualmente, de um estado de letargia profunda, morte aparente, descobri que eu estava num lugar extremamente agressivo. Havia lido há pouco tempo o infermo de Dante e tive a clara impressão de que eu estava num daqueles patamares atormentado por uma luz ofuscante, sem perspectivas de espaço ou tempo.

Nesse lugar indefinido, vozes as mais desencontradas eram ouvidas, pacientes sofrendo suas "malaises", atendentes de enfermagem dando ordens aos pacientes para que estes se comportassem, médicos conversando sobre sua cabeça um discurso incompreensível, mas ameaçador.

Gostaria de relatar algumas das minhas alucinaçōes decorrentes do mundo em que eu estava situado. Chega-se uma atendente e me olha com um olhar penetrante, agressivo e ameaçador e me diz - "O senhor está em jejum absoluto e vai ficar assim". Para mim não fazia qual-

* Professor Emérito - PUC - SP 
quer diferença, pois no momento eu não sabia onde estava e qual era o significado do que me dizia aquela pessoa.

Algumas vezes tive a impressão de que eu estava num lugar como o "limbo", por exemplo, aquele lugar onde, segundo a teologia católica posterior ao século XIII se situam as almas das crianças que embora não tivessem alguma culpa pessoal morieram sem o batismo. A metáfora aquı usada como "limbo" é para indicar que eu me sentia no inferno. O que me dava esse sentimento agoniante de tortura eram as luzes contínuas e ofuscantes. Os olhos pareciam saltar das órbitas e não havia qualquer lenitivo.

Nesse primeiro período que eu não posso precisar seguramente em horas e dias, pois a noção de espaço e tempo foram completamente perdidos, eu me sentia como um corpo animado por algo externo e nada interno.

Ao recuperar minha noção de lugar, de situação, comecei a observar onde estava. Até então eu não sabia que estava numa UTI. Vi, que estavamos todos nús, com apenas uma coberta muito tênue sobre nossos corpos. Senti, outra vez, que estava numa condição de vida extra-terrena. Não era possível que humanos, num mundo humano, fossem tratados assim. A situação de extra-terrenidade era dada à medida que circulavam vultos em linhas retas e curvas, sem se deterem em lugar algum.

Os médicos, este eram os mais desvinculados de qualquer ligação humana com os pacientes. Tenho a mais profunda aversão pelo tratamento que recebi. Sem dúvidas o sôro, como uma árvore de natal colocada na jugular, funcionou muito bem. Não pude ver a fisionomia do médico que colocou esse sôro, tão distante e impessoal.

Felizmente, pertenço à Unicamp e à PUCSP e ambas as Universidades possuem Escolas de Medicina. Recebi, para desconforto e desprazer do médico diretor da UTI visitas contínuas e constantes dos médicos meus amigos e que me conhecem de longa data. Sei perfeitamente bem, quão inconveniente pode ser para um diretor de UTI precisar dar atenção a médicos que vêm visitar pacientes. Entretanto, não se trata de um lugar de abandono, Limbo ou Acheron: Charon, primeiro vestíbulo do Inferno, mas de uma dependência do hospital.

Em alguns momentos, agora que eu estava mais senhor de mim mesmo, vi pessoas morrendo ao meu lado, outros angustiados gritando, mais adiante outros, ainda, num completo distanciamento de qualquer realidade, abandonados aos seus próprios recursos. Nesse momento de maior domínio de mim mesmo comecei a descobrir algumas atendentes com características mais humanas que vinham e se dirigiam a mim perguntando como estava me sentindo. Uma certa ocasião, um médico que circulava pela UTI, chegou-se a mim, e eu ainda estava num estado semi-consciente, e disse-me que um dos meus orientandos na PUC-SP fazia doutoramento e iria defender sua tese naquele dia. Fiquei profundamente transtomado e disse que desejava muito estar presente. Foi quando chegou um atendente do sexo masculino e, brutalmente amarrou minhas mãos e meus pés nas grades da cama. Foi, então, que eu senti que ia mesmo morrer, pois perdera todo o tonus muscular e a energia que me animava. Assim fiquei, amarrado de pés e mãos, durante um tempo indeterminado.

Poderia continuar relatando episódios após episódios, pois foram muitos. Não seria produtivo esta sequência. Parece-me que aqueles que lerem este artigo aproveitarão muito mais se acompanharem meu progresso emocional diante da UTI. Com o passar dos meses, e com o restabelecimento rápido, comecei a sentir menos antagonismo diante da UTI. Senti que talvez não fosse possível outra maneira de agir. Dias após dias, pacientes após pacientes, levam a uma familiaridade com o infortúnio da doença e esta passa a ser o quotidiana, isto é, aquilo mais próximo de toda aquela equipe. Comecei até ver com mais complacência o trabalho exaustivo que deve ser o do atendente de enfermagem e mesmo da enfermeira. Não consigo, porém, encontrar qualquer compreensão para o trabalho do médico. Parece que em UTI os médicos tornam-se mais profissionais e menos humanos. Isto se verifica no seu discurso e na maneira de tratar o peciente. Há uma crença entre os profissionais de saúde de que o paciente é um ser regressivo e que necessita tratamento de choque para reagir. Posso afirmar que há aqui um lêdo engano, quanto mais regressivo, se este for o caso, mais atenção humana é necessário para compensar a regressão e permitir que o paciente se encontre. Não há qualquer dúvida que um paciente de UTI deseja sair de lá o mais breve possível. Se conseguir viver, muito bem, se morrer, deixa este mundo em paz, com um tratamento humano que dignifica a sua morte. 